University of Louisville

ThinkIR: The University of Louisville's Institutional Repository

Faculty Scholarship

$7-2021$

\title{
US Gambling Stagnation: Will New Gambling Forms Make a Difference?
}

Thomas E. Lambert

University of Louisville, thomas.lambert@louisville.edu

Follow this and additional works at: https://ir.library.louisville.edu/faculty

Part of the Business Commons, and the Economics Commons

\section{ThinkIR Citation}

Lambert, Thomas E., "US Gambling Stagnation: Will New Gambling Forms Make a Difference?" (2021).

Faculty Scholarship. 533.

https://ir.library.louisville.edu/faculty/533

This Working Paper is brought to you for free and open access by ThinkIR: The University of Louisville's Institutional Repository. It has been accepted for inclusion in Faculty Scholarship by an authorized administrator of ThinkIR: The University of Louisville's Institutional Repository. For more information, please contact thinkir@louisville.edu. 


\title{
US Gambling Stagnation: Will New Gambling Forms Make a Difference?
}

\author{
by \\ Thomas E. Lambert \\ Applied Economist \\ College of Business \\ University of Louisville \\ Louisville, KY 40292 \\ E-mail: Thomas.Lambert@Louisville.edu \\ Phone: 502-852-7838
}

\begin{abstract}
Much has been written recently in the popular press about the rise of sports gambling, historical horse racing or instant racing (HHR), and esports. However, despite this, some note an overall decline in the popularity of gambling and gaming in general as horse racing (pari-mutuel) wagering has declined dramatically over the decades and as casino and lottery revenues have fallen slightly since before the Great Recession. This exploratory research note examines the trends in US gambling over the last several decades and explores whether the new forms of gambling will stem and reverse overall gambling stagnation in the United States. Despite reports of new gambling outlet successes, it appears that sports gambling, HHR, and esports have not done much to stop the overall fall in gambling revenues. This is probably due to stagnant disposable personal income growth.
\end{abstract}

JEL Code: Z21

Key words: betting, casinos, esports, gambling, horse racing, lotteries, parimutuel wagering, sports gambling 
"I spent half my money on gambling, alcohol and wild women. The other half I wasted."

$\sim$ W. C. Fields

\section{Introduction}

New Jersey was the first state to legalize sports gambling outside of Nevada after a landmark US Supreme Court decision in May 2018 struck down a federal law banning sports gambling in all other states and the District of Columbia (Liptak and Draper 2018). Some race tracks such as Monmouth Park race track began offering sports gambling as a way to bring back fans to parimutuel wagering which had been in decline for several decades at tracks throughout the nation (Associated Press 2019). Per capita casino and casino hotel revenues have also stagnated when adjusted for inflation since before or after the Great Recession (Srinivasan and Lambert 2015) as have per capita lottery sales when adjusted for inflation since the Great Recession. See Figures 1 to $4 .{ }^{1}{ }^{, 2}$ The total number of casinos in the US has also declined since reaching a peak of 524 in 2016 and falling to 465 in 2019 (American Gaming Association 2020), and the total number of horse races held in the US has fallen around 50\% since 1989 (US Jockey Club 2021) as the on-site portion of the gambling industry has shrunk in size. This brief paper examines trends in the United States on how sports gambling and esports gambling have grown when compared to parimutuel wagering, lotteries, and casino revenues since mid-2018. It appears initially that sports and esports gambling have failed to bring in any resurgence in overall gambling in the US, and instead have probably and mostly taken away revenues from other venues for gambling. These trends appear to have existed before the Covid-19 pandemic

\footnotetext{
${ }^{1}$ US per capita estimates are used in order to help assess market share growth over time since it is hard to find estimates of market size in terms of people for each form of gambling if not the size of the overall gambling consumer market. It is also useful in trying to standardize the data comparisons made in this paper.

${ }^{2}$ All inflation adjustments use an Urban Consumer Price Index with a base year of 1982-1984 as provided by the US Bureau of Labor Statistics (US Bureau of Labor Statistics, no date).
} 
peak during 2020 and are somewhat ironic in that until the 1970s gambling outside of horse racing had great difficulty gaining acceptance among the US public and then took off with the proliferation of lotteries and casinos in different states in the 1980s and 1990s (Madhusudhan 1996, Guell 2010, Lambert 2021).

(Insert Figures 1 to 4 around here)

Figure 5 illustrates stagnation in per capita and inflation adjusted personal, consumption expenditures for gambling in general, which has had difficulty getting back to 2008 levels even if the dramatic drop in 2020 due to the Covid-19 pandemic is ignored. Additionally, as Figure 6 shows, gambling has undergone a decline as a percentage of recreational spending since reaching a peak in 2006, and it has also declined as a share of disposable personal income since its peak in 2007 (see Figure 7). This is probably not surprising given the downward trend in growth in real disposable personal income per capita over the last several decades as shown in Figure $8^{3}$ and as personal consumption expenditures (PCE) have become a smaller part of DPI since the Great Recession (Figure 9). The post Great Recession period shows a worsening of the anemic growth in DPI.

(Insert Figures 5 to 10 around here)

\section{Recent Gambling Innovations}

As an antidote to the decline of the popularity of live horse racing, instant racing or HHR, which uses a slot machine type device that employs and gives pay outs for races held in the past, has become popular over the last 15 years or so. Yet revenues for this are already included as

\footnotetext{
${ }^{3}$ Figure 8 's trend line has an equation of $y=-0.018 x+2.3889$ so that as each year has passed since 1959 real DPI per capita has declined about $0.018 \%$ per year on average.
} 
pari-mutuel wagering, and so if anything, HHR has only prevented horse racing wagering from appearing worse than what it would be otherwise. In fact, in Kentucky, HHR now accounts for at least two-thirds or more of pari-mutuel wagering revenues as the number of actual races held per year continues to decline in the state and throughout the US (Kentucky Horse Racing Commission 2019, Lambert 2021).

The popularity of esports, online poker, and major league and collegiate sports gambling has climbed dramatically over the last few years, especially as sports gambling, which basically takes in esports gambling, has become legal in more and more states since mid-2018. Figure 10 shows the growth of total sports gambling dollars on a per capita monthly basis since June 2018 to April 2021 as the number of states offering sports gambling went from one (Nevada) in 2018 to over 20 and the District of Columbia by 2021. The number of states legalizing sports gambling is forecasted to continue to climb (American Gaming Association 2021). The gambling amounts show peaks and valleys during any given year with gambling revenues climbing during football season and Major League Baseball's World Series and then peaking around the time of the NFL playoffs and Super Bowl season during December and January of each year. They then decline until college basketball's NCAA playoff tournament held in March of every year. Some states require on site sports gambling whereas others allow this as well as the use of online gambling (American Gaming Association 2021), and, according to the US Bureau of Economic Analysis (BEA), sports gambling revenues are classified as casino revenues. In fact, all legal gambling outside of lotteries and pari-mutuel wagering is grouped by the BEA under casinos. ${ }^{4}$ Therefore, despite the gains shown in Figure 10, these amounts are

\footnotetext{
${ }^{4}$ Please see the appendix for a copy of an email note from the US BEA clarifying this. The author can furnish or forward the actual correspondence upon request.
} 
already embodied in the graph in Figure 2, which means that sports gambling will have to continue to grow dramatically to make up for inflation adjusted casino revenue declines over the last 15 years or so. However, sports gambling could also take away revenues from other gambling outlets as have the growth of lotteries and casinos taken away revenues from parimutuel wagering (Lawrence and Thalheimer 1999, Thalheimer and Ali 2008, Lambert 2021) or as online gambling has taken consumers away from attending "bricks and mortar" casinos (Philander 2011)..$^{5,6}$

\section{Possible Reasons for Gambling's Stagnation}

So what can possibly be the causes of gambling's stagnation, or much worse, its possible decline? Part of the problem is a change in consumer preferences toward gambling as noted in a study by Welte, Barnes, and Tidwell (2015) and an article by Hwang (2015). Especially noted in the articles is the smaller amounts spent by younger gamblers than their predecessors in other generations, although gambling is still more popular among younger males rather than women and middle aged and older consumers according to Welte, Barnes, and Tidwell 2015. However, Bokunewicz (2016) writes that her study show less interest in general by millennials toward most forms of gambling. Meanwhile the number of "problem gamblers" or those with a gambling addiction has plateaued over the last 20 years or so as gambling in the US has proliferated, a

\footnotetext{
${ }^{5}$ Regarding state and local economic development efforts, gambling has been found to have mixed results according to Eadington (1999) whereas Walker (2007) claims positive impacts. Walker and Jackson (2007) find few long-term net benefits for casinos, however. Guell (2010) claims that tax revenues from casinos often fail to live up the expectations of state and local governments and that any additional spending on gambling in a locality harms spending on restaurants, theaters, and other forms of recreation through a substitution effect. Collins (2003, pages 113-117) claims that most of the money spent on new forms of gambling, or those forms previously prohibited in certain jurisdictions, almost always comes at the expense of previously existing forms of local gambling.

${ }^{6}$ The possible saturation of different forms of gambling hurts each establishment within a given region but apparently maximizes tax revenues for state and local governments (Srinivasan and Lambert 2015). This paper examines gambling from a US economy wide perspective, so gambling outlets saturation should boost, not hinder, aggregate gambling spending.
} 
phenomenon that has been found in other nations as gambling venues have increased (Welte, Barnes, and Tidwell 2015).

Also, the "hold percentage", or the amount of an establishment's withholdings from gamblers' winnings for operating expenses, taxes, etc., has gone up over the last few decades, which in turn lessens gamblers' winnings, and therefore any increases in hold percentage due to possible tax increases may be contributing to a decrease in gambling activity. Srinivasan and Lambert (2017) along with others (Thalheimer and Ali 2003, Navin and Sullivan 2007, Dadayan 2015) find that higher state tax rates on casinos in certain states depress casino revenues and their corresponding tax remittances to state governments, and this is primarily because greater hold by the casinos lower patron attendance and overall gambling. ${ }^{7}$ This is because gambling is price elastic, and less winnings by patrons because of higher hold rates basically raise the price of gambling to patrons. These papers also note that casino proliferation helps to increase overall state tax revenues but at the expense of lower revenues per casino, which is a bad effect on the industry and implies a saturation effect among casinos in different regions. Unfortunately, not much data exists for a comprehensive hold rate (operating expense, profits, taxes, etc.) for all forms of gambling across all states, and so to assess the impacts of hold, and even specifically the taxes on gambling institutions, is difficult to assess at the aggregate level. ${ }^{8}$

Additionally, as noted above, real disposable personal income and its slower growth has been described as a factor affecting overall gambling revenues, and the importance of DPI to

\footnotetext{
7 Thalheimer and Ali (1995) find that higher tax rates also depress pari-mutuel wagering.

${ }^{8}$ US Federal government taxes on gambling winnings by patrons are withheld at most casinos, lottery organizations, and race tracks if the winnings are over a certain amount such as at least several thousand dollars or more ( $\$ 5000$ as of 2020$)$. At the same time, gambling losses are often deductible on federal income taxes (US Internal Revenue Service 2021). Taxes on institutions are usually passed on to patrons in the form of less payouts on gambling winnings.
} 
gambling is mentioned in various articles (Nichols 1998, Thalheimer and Ali 2008, Marionneau and Nikkinen 2018, Lambert 2021). And finally, if labor force participation rates drive macroeconomic real household income and real disposable personal income, the claim by some that declining growth in DPI is partially due to declines in labor force participation rates across all groups, especially younger males (ages 16-24) (Hipple 2016) needs to be examined too.

Unfortunately, the research for this paper could not find data that indicates spending on gambling by different age segments over time or overall or on average hold rates for gambling over time in the US. One of the main purposes of this paper is to examine and assess long term trends in gambling, and no real trend data could be found for these factors that could be possibly affecting real gambling expenditures over time. Nonetheless, there is data for US labor participation rates and real disposable personal income per capita over the last several decades that can be used to assess the impact of these variables on per capita real gambling expenditures. Furthermore, if labor force participation rates have gone down because of so many of the members of the baby boomer generation retiring, less labor force participation among women, less among teenage and younger workers, and less among men in general (Canon, Kudlyak, Debbaut 2013), and if real disposable personal income has gone down as a result of lower labor force participation overall, then one reason for less millennial gambling could be their lower labor participation rates and lower, real DPI (and this could be the same for all ages or generational groups).

At the same time, if real DPI is growing more slowly over the last two decades than in the past, then any increases in hold rates would be more difficult for gambling consumers to accept with stagnating DPI versus those times when it was growing more robustly. That is, the concept of real DPI somewhat captures the notion of gambling consumers being able to handle 
or contend with price increases such as handle increases on gambling. As real DPI stagnates, it becomes more difficult for consumers to accommodate price increases for recreational goods such as gambling. Finally, the decline in the interest in gambling, especially among younger consumers, could be a symptom of declines in real DPI per capita. That is, if real DPI income per capita is declining, then so would be interest in gambling among different demographic groups.

\section{Hypothesis Testing and Results}

(Insert Table 1 around here)

The following two hypotheses are offered as a way to assess long-run gambling growth and stagnation:

1. Younger males are gambling less than their cohorts from previous generations because fewer participate in the labor force, and so this has caused gambling revenues to tumble over the last twenty years or so. Young male (ages 16 to 24) participation rates in the labor force from 1959 to 2020 (US Bureau of Labor Statistics (BLS) 1959-2020) are used as proxies for young male consumer spending. US BLS numbers show this age group's participation rate peaking in 1979 at around $75 \%$ and falling to $56 \%$ by $2019 .^{9}$

2. Lower gains in real disposable personal income per capita over the last two decades versus previous decades have led to lower expenditures on gambling. DPI is cited in the literature as a key determinant of gambling and other forms entertainment

\footnotetext{
9 The US BLS has data on expenditures per different demographic groups, one of which is age groups, from surveys of households. These only go back to 1989, however, and for each year given it is not possible to pinpoint spending according to gender, and spending on gambling is not listed (US BLS Consumer Expenditures Survey 1989-2019).
} 
spending, and so one would expect that slower growth in real DPI could lead to lower growth in real gambling expenditures per capita. The values of inflation adjusted, per capita DPI as illustrated in Figure 5 are used for this variable (US BEA 19592020).

Table 1 shows the results of using these two factors to predict inflation adjusted, per capita gambling expenditures from 1959 to 2020 . Even when observations are dropped for the Covid-19 pandemic year of 2020, the results do not change that much. See Table A1 in the Appendix. Because of problems of serial correlation, Newey-West standard errors are used. No signs of collinearity are detected with no variance inflation factor greater than 5.0. All of the variables are in natural log form so as to do some sensitivity analysis of how a change in the independent variables correlate with the dependent variable.

The variable for young male labor force participation rates is not statistically significant, yet the one for real disposable income is significant at an alpha of 5\%. The overall explanation of variance in real gambling expenditures per capita is around $94 \%$, which is strong result. It appears that a $1 \%$ increase in real DPI per capita is associated with a $3.13 \%$ increase in real gambling expenditures per capita, on average and all else held constant. This result shows that at the aggregate level that gambling is a luxury or superior good in that its income elasticity in this case, 3.13 , is greater than 1.0. This is consistent with the much of the gambling literature cited in this paper. One would expect that the lower the increase in real DPI, the lower the increase in real gambling expenditures. Therefore, the lower increases or occasional decreases in real DPI over the last two decades or so have resulted in slower or negative gambling growth as opposed to the greater and more positive growth experienced by it in the 1960s and through to the 1990s. 


\section{Conclusion}

The exploratory work done for this short paper/note shows some support for the notion that stagnating disposable personal income in the US has caused slow growth and/or some decline in aggregate real gambling expenditures over the last 15 years or so. A shortcoming of the paper is the inability to find a variable that would replicate the spending habits of young males, those who are thought to be the biggest consumers of gambling services and products. Additionally, the impact that higher hold rates may have on gambling expenditures over time is another item missing from the paper because of a lack of comprehensive, national database on hold rates, although as argued above, strong gains in DPI could/should offset any increases in hold rates at gambling outlets. Weaker gains or even losses in DPI would make it more difficult for patrons to accommodate any increases in gambling holds, and so the real DPI variable possibly captures some of the effect of greater holds driving away gambling customers.

Nonetheless, the evidence presented in this brief analysis suggests that slowing or even declining rates of increases in real DPI have hindered the gambling industry in terms of real growth either a few years before or since the Great Recession of 2007-2009. For horse racing and casinos, the sluggish growth appears to have started before the recession. All of this is despite an economic recovery that lasted until the pandemic of 2020.

There is a large volume of writings on the causes of US stagnating wages and income that has occurred since the mid to late 1970s that is too long to list here. Among the reasons for the stagnation are the decline in union membership among US workers; the offshoring of jobs that used to be located in the US; the automation of many jobs that used to require human workers; the falling productivity of most US workers; the decline in US capital investment; and the growth of laws giving employers greater strength in the labor market. These topics are beyond 
the scope of this paper, yet they can offer some explanation as to why real DPI is not doing as well as it did during earlier eras.

Sports gambling, already being factored into overall gambling spending by being counted in the revenues for casinos, therefore probably only offers a hope to resuscitate gambling if real DPI begins to grow at higher rates again and as long as it does not take away an equal share of gambling from other forms of gambling. The literature reviewed for this paper indicates that the latter scenario is highly likely, and given the economic record of most of the $21^{\text {st }}$ Century so far, the former appears unlikely unless something causes incomes to rise at higher rates. 


\section{References:}

American Gaming Association. 2020. State of the States 2020. Published by American Gaming Association. https://www.americangaming.org/resources/state-of-the-states2020/. Accessed on June 27, 2021.

American Gaming Association. 2021. Interactive Map: Sports Betting in the U.S. https://www.americangaming.org/research/state-gaming-map/ . Accessed on June 22, 2021.

Associated Press, "Horse racing weighs changes to compete with sports gambling", May 1, 2019, USA Today. https://www.usatoday.com/story/sports/horseracing/2019/05/01/horse-racing-weighs-changes-tocompete-with-sports-gambling/39428431/ . Accessed on December 25, 2019.

Bokunewicz, Janet. 2016. Millennial Entertainment Preferences Study Final Report-July 2016. Lloyd D. Levinson Institute of Gaming, Hospitality, and Tourism, Stockton University, Stockton, NJ. https://www.documentcloud.org/documents/3111163-Millenial-EntertainmentPreferences-FINAL-REPORT.html . Accessed on June 27, 2021.

Canon, Maria E., Marianna Kudlyak, Peter Debbaut. 2013. "A Closer Look at the Decline in the Labor Force Participation Rate." The Regional Economist. October 2013. Published by the US Federal Reserve Bank of St. Louis.

Collins, Peter. 2003. Gambling and the Public Interest. Westport, CT: Praeger Press.

Dadayan, Lucy and Robert B. Ward. 2011. "Back in the Black: States' Gambling Revenues Rose in 2010." June 23, 2011. Albany, NY: Nelson A. Rockefeller Institute of Government. Accessed August 15, 2011. http://www.rockinst.org/pdf/government_finance/2011-06-23Back_in_the_Black.pdf. Accessed on June 25, 2021.

Eadington, William, R. 1999. "The Economics of Casino Gambling." Journal of Economic Perspectives, 13 (3): 173-192.DOI: 10.1257/jep.13.3.173 . Accessed on June 27, 2021.

Fields, W.C. 1880-1946. AZQuotes. https://www.azquotes.com/author/4795-W_C_Fields . Accessed on June 27, 2021.

Guell, Robert C. 2010. "Chapter 43: The Economic Impact of Casino Gambling," Issues in Economics Today, 5th Edition, McGraw-Hill Publishers. New York, New York.

Steven F. Hipple, "Labor force participation: what has happened since the peak?," Monthly Labor Review, U.S. Bureau of Labor Statistics, September 2016, https://doi.org/10.21916/mlr.2016.43 . Accessed on June 25, 2021.

Hwang, Jeff. 2015. “The Millennial Problem: Why We (Don't) Gamble." The Motley Fool. https://www.fool.com/investing/general/2015/09/19/the-millennial-problem-why-we-dontgamble.aspx . Accessed on June 25, 2021. 
IBISWorld. December 22, 2020. Market size of the casino hotel sector in the United States from 2011 to 2020, with a forecast for 2021 (in billion U.S. dollars) [Graph]. In Statista. Retrieved June 22, 2021, from https://www-statista-com.echo.louisville.edu/statistics/1174152/casinohotels-industry-market-size-us/

Kentucky Horse Racing Commission. 2019. 2019 Fiscal Year Pari-Mutuel Wagering Reports. https://khrc.ky.gov/new_docs.aspx?cat=76\&menuid=80 . Accessed on June 22, 2021.

Lambert, Thomas E. 2021. "Kentucky and the Thoroughbred Industries: Prospects and Challenges as Gambling Stagnates" (2021). Faculty Scholarship. 517. https://ir.library.louisville.edu/faculty/517 . Accessed on June 23, 2021.

Lawrence, Robert G. and Richard Thalheimer. 1999. "An Economic Analysis of the Effects of Casino Gambling on the Kentucky Horse Race Industry." In The Business of Gaming: Economic and Management Issues, William R. Eadington and Judy A. Cornelius, Eds. Reno, NV: Institute for the Study of Gambling and Commercial Gaming, University of Nevada at Reno.

Legal Sports Report. 2018-2021. US Sports Betting Revenue and Handle.

https://www.legalsportsreport.com/sports-betting/revenue/ Accessed on June 2021.

Liptak, Adam and Kevin Draper. 2018. "Supreme Court Ruling Favors Sports Betting." The New York Times, May 14,2018. https://www.nytimes.com/2018/05/14/us/politics/supremecourt-sports-betting-new-jersey.html . Accessed on June 7, 2021.

Madhusudhan, Ranjana G. 1996. Betting on Casino Revenues: Lessons From State Experiences, National Tax Journal, 49:3, pp. 401-12.

Marionneau, V., \& Nikkinen, J. 2018. Market Cannibalization Within and Between Gambling Industries : A Systematic Review. Journal of Gambling Issues, 37, January 2018: 1-35.

Navin, John C., and Timothy S. Sullivan. 2007. Do Riverboat Casinos Act as Competitors? A Look at the St. Louis Market." Economic Development Quarterly. 21 (1): 49-59.

Nichols, M.W. 1998. Deregulation and Cross-Border Substitution in Iowa's Riverboat Gambling Industry. J Gambl Stud 14, 151-172 (1998). https://doi.org/10.1023/A:1023046809126.

Philander, K. S. (2011). The Effect of Online Gaming on Commercial Casino Revenue. UNLV Gaming Research \& Review Journal, 15(2). Retrieved from https://digitalscholarship.unlv.edu/grrj/vol15/iss2/5. Accessed on June 27, 2021.

Srinivasan, A.K. and Lambert, T.E. (2017), The Impact of Stagnating Casino Revenues on State and Local Governments Tax Receipts. Public Budgeting \& Finance, 37: 26-46.

https://doi.org/10.1111/pbaf.12123.

Thalheimer, R., and M. M. Ali. 1995. "The Demand for Parimutuel Horse Race Wagering and Attendance" Management Science, v41, 129-143. 
Thalheimer, R., and M. M. Ali. 2003. "The Demand for Casino Gaming” Applied Economics, v35,907-918.

Thalheimer, R., \& Ali, M. 2008. "Pari-Mutuel Horse Race Wagering-Competition from Within and Outside the Industry." In Handbook of Sports and Lottery Markets, Hausch Donald B. and William T. Ziemba, eds. Amsterdam, Netherlands: Elsevier Publishers.

US Census Bureau. 1960-2019. "Population and Housing Unit Estimates Datasets." https://www-census-gov.echo.louisville.edu/programs-surveys/popest/data/data-sets.All.html Accessed on June 25, 2021.

U.S. Bureau of the Census, 1998-2018, Total Revenue for Casinos Excluding Casino Hotels, Establishments Subject to Federal Income Tax, Employer Firms [REVEF71321TAXABL], retrieved from FRED, Federal Reserve Bank of St. Louis;

https://fred.stlouisfed.org/series/REVEF71321TAXABL, Accessed on June 21, 2021.

US Bureau of the Census. 1929-2020. Population and Housing Unit Estimates.

https://www.census.gov/programs-surveys/popest/data.html . Accessed on June 22, 2021.

U.S. Bureau of Economic Analysis, 1930 to 2020, Real Disposable Personal Income: Per Capita [A229RX0], retrieved from FRED, Federal Reserve Bank of St. Louis;

https://fred.stlouisfed.org/series/A229RX0 , Accessed on June 21, 2021.

U.S. Bureau of Economic Analysis. 1959-2020. Table 2.4.5U. National Income and Product Accounts, Personal Consumption Expenditures by Type of Product, https://apps.bea.gov/iTable/iTable.cfm?reqid=19\&step=3\&isuri=1\&1921=underlying \&1903=20

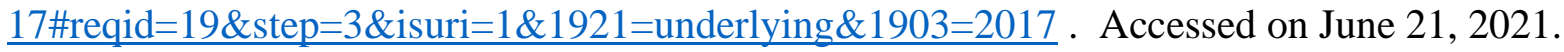

U.S. Bureau of Economic Analysis. 1959-2020. Table 2.1. Personal Income and Its Disposition, https://apps.bea.gov/iTable/iTable.cfm?reqid=19\&step=3\&isuri=1\&1921=survey\&1903=58\#req $\underline{\mathrm{id}=19 \& \text { step }=3 \& \mathrm{isuri}=1 \& 1921=\text { survey } \& 1903=58}$. Accessed on June 21, 2021.

U.S. Bureau of Economic Analysis, 1959 to 2020. Personal consumption expenditures: Services: Gambling [DGAMRC1A027NBEA], retrieved from FRED, Federal Reserve Bank of St. Louis; https://fred.stlouisfed.org/series/DGAMRC1A027NBEA, Accessed on June 21, 2021.

US Bureau of Labor Statistics. No date. "Consumer Price Index US City Average (1982-84 = 100).” https://www.bls.gov/regions/new-england/data/consumerpriceindex_us_table.htm . Accessed on June 25, 2021.

US Bureau of Labor Statistics. 1959-2020. Labor Force Statistics from the Current Population Survey. Series Id: LNS11324887, Seasonally Adjusted, Series title: (Seas) Labor Force Participation Rate - 16-24 yrs. Labor force status: Civilian labor force participation rate https://data.bls.gov/PDQWeb/ln . Accessed on June 29, 2021.

US Bureau of Labor Statistics. 1989-2019. Consumer Expenditure Surveys. https://www.bls.gov/cex/tables.htm . Accessed on June 29, 2021. 
US Internal Revenue Service. 2021. “Topic No. 419 Gambling Income and Losses.” Internal Revenue Service. Last updated March 9, 2021.

US Jockey Club and Equibase Company LLC, CHRIMS (Comprehensive Horse Racing Information Management Systems), and Hipodromo Camarero, 1989-2020. 2021 Fact Book. http://jockeyclub.com/default.asp?section=FB\&area=8 . Accessed on June 22, 2021.

Walker, Douglas M. 2007. The Economics of Casino Gambling. Berlin: Springer.

Walker, D.M. and Jackson, J.D. (2007), Do Casinos Cause Economic Growth?. American Journal of Economics and Sociology, 66: 593-607. https://doi.org/10.1111/j.15367150.2007.00528.x . Accessed on June 27, 2021.

Welte, J.W., Barnes, G.M., Tidwell, MC.O. et al. 2015. "Gambling and Problem Gambling in the United States: Changes Between 1999 and 2013", Journal of Gambling Studies 31, 695-715 https://doi.org/10.1007/s10899-014-9471-4 . Accessed on March 15, 2021.

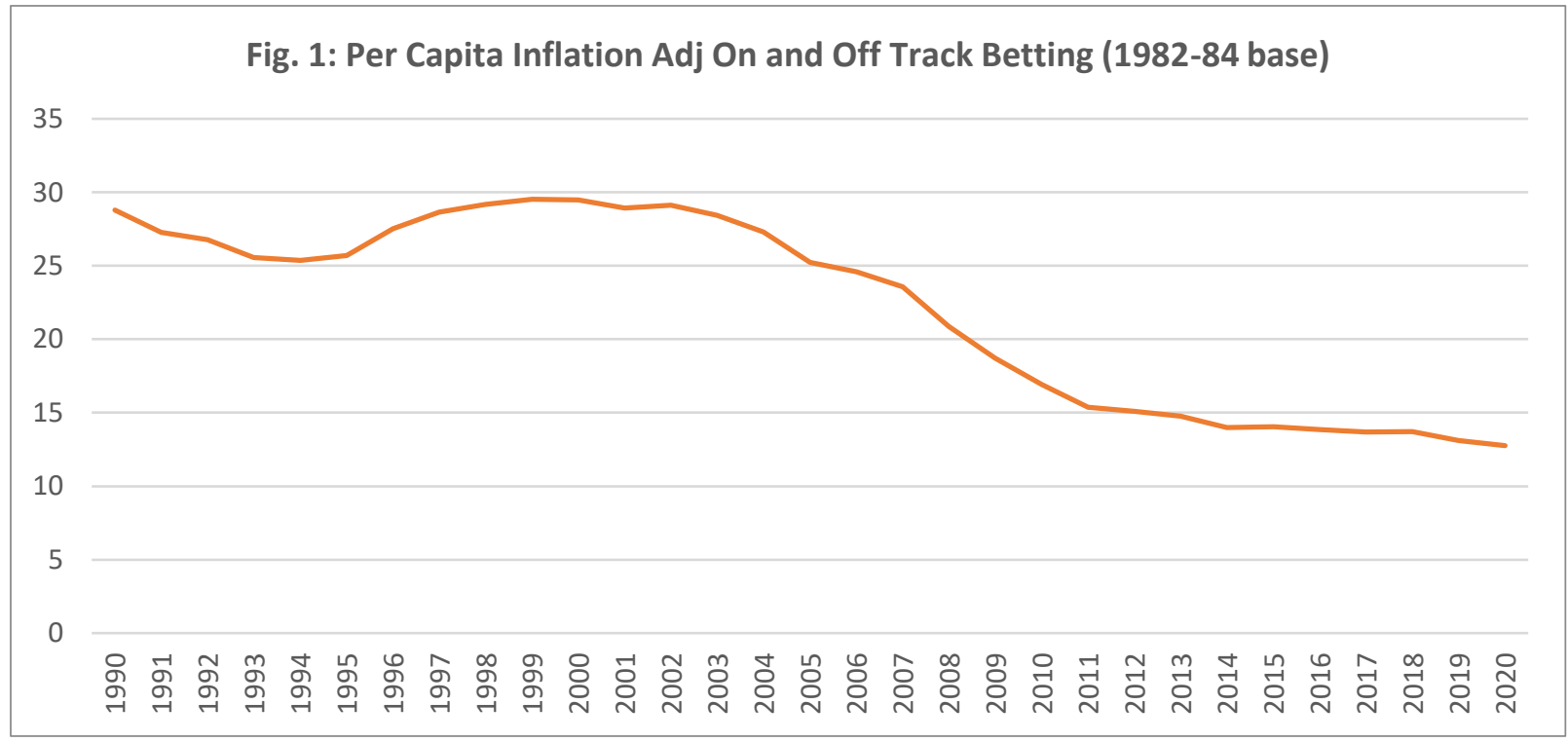

Source: US Jockey Club and Equibase Company LLC, CHRIMS (Comprehensive Horse Racing Information Management Systems), and Hipodromo Camarero, 1990-2020.

http://jockeyclub.com/default.asp? section=FB\&area=8 . Accessed on June 22, 2021.. 
Fig. 2: Per Capita Inflation Adj Casino Revenues (1982-84 base)

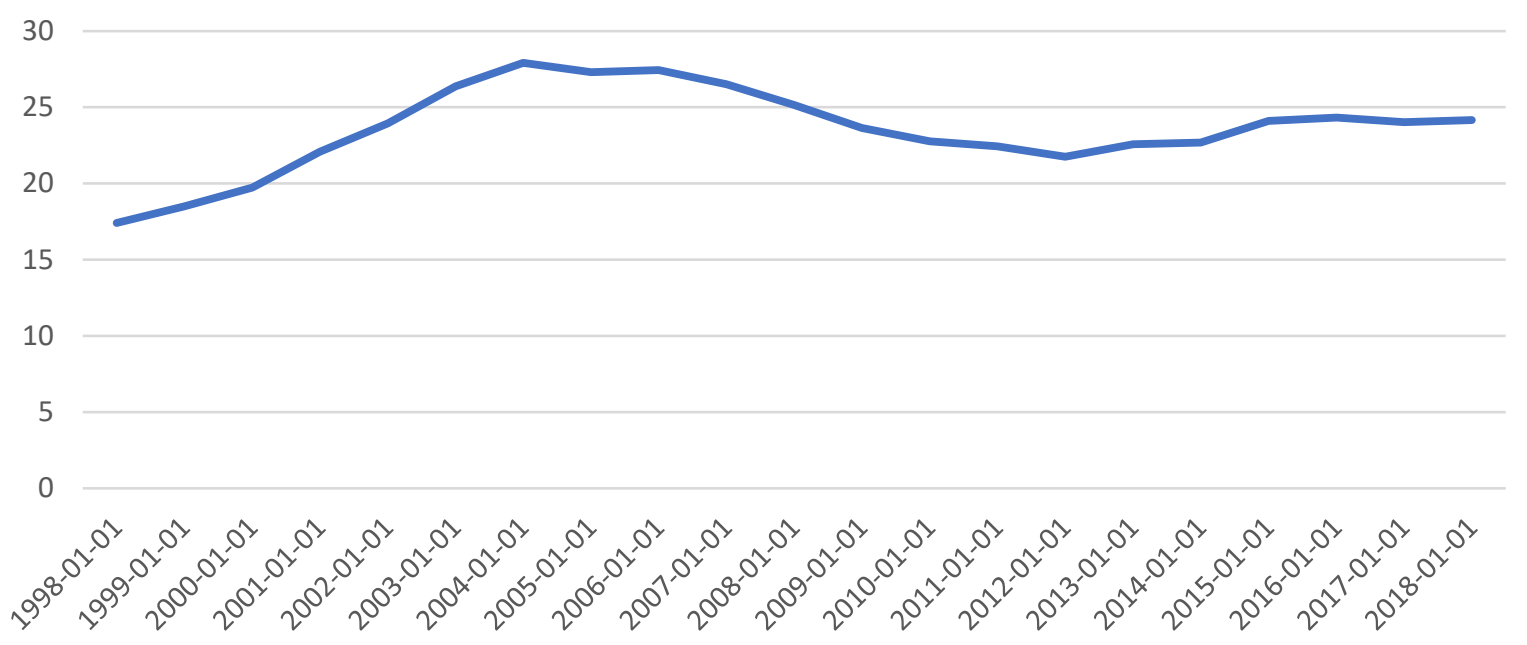

U.S. Census Bureau, Total Revenue for Casinos Excluding Casino Hotels, Establishments Subject to Federal Income Tax, Employer Firms [REVEF71321TAXABL], retrieved from FRED, Federal Reserve Bank of St. Louis; https://fred.stlouisfed.org/series/REVEF71321TAXABL, June 22, 2021

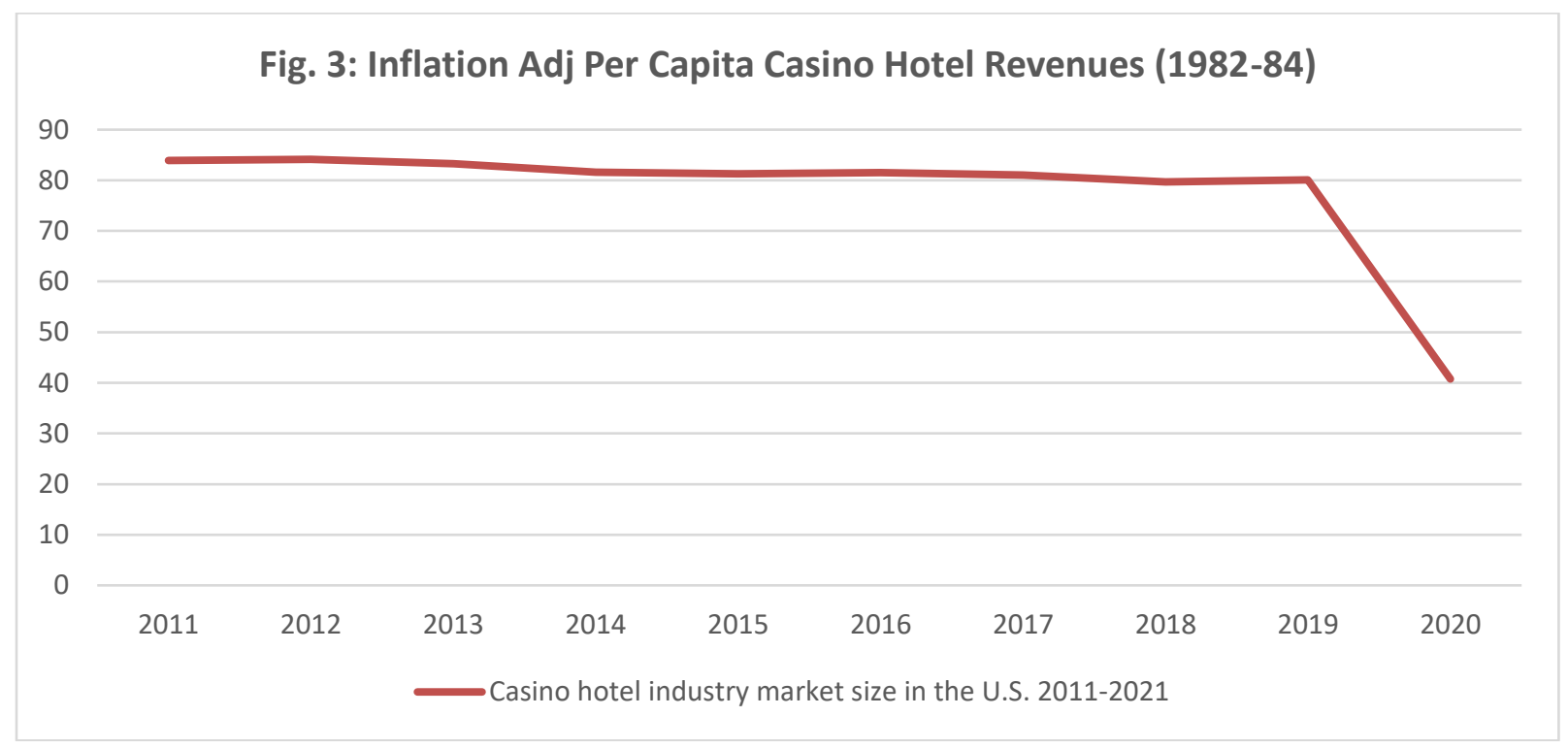

Source: IBISWorld. (December 22, 2020). Market size of the casino hotel sector in the United States from 2011 to 2020, with a forecast for 2021 (in billion U.S. dollars) [Graph]. In Statista. Retrieved June 22, 2021, from https://www-statista-com.echo.louisville.edu/statistics/1174152/casino-hotels-industrymarket-size-us/ 


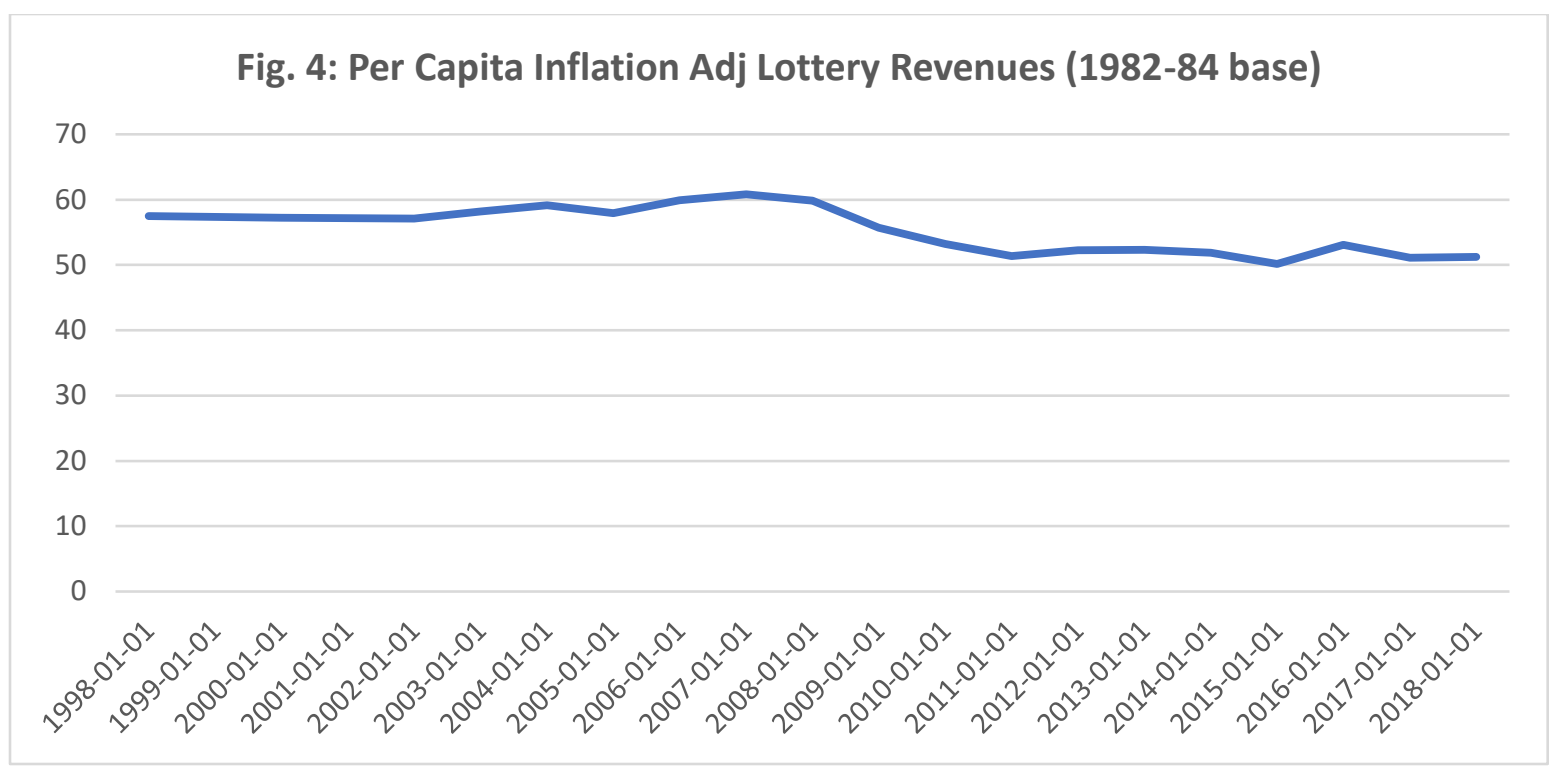

Source: US Census Bureau. 1977-2018, updated annually. Annual Survey of State and Local Government Finances, 1977-2018. Compiled by the Urban-Brookings Tax Policy Center. Washington, DC:

Urban-Brookings Tax Policy Centers (1977-2018). Date of Access: (30-Mar-2020).

https://www.taxpolicycenter.org/statistics/lottery-revenue

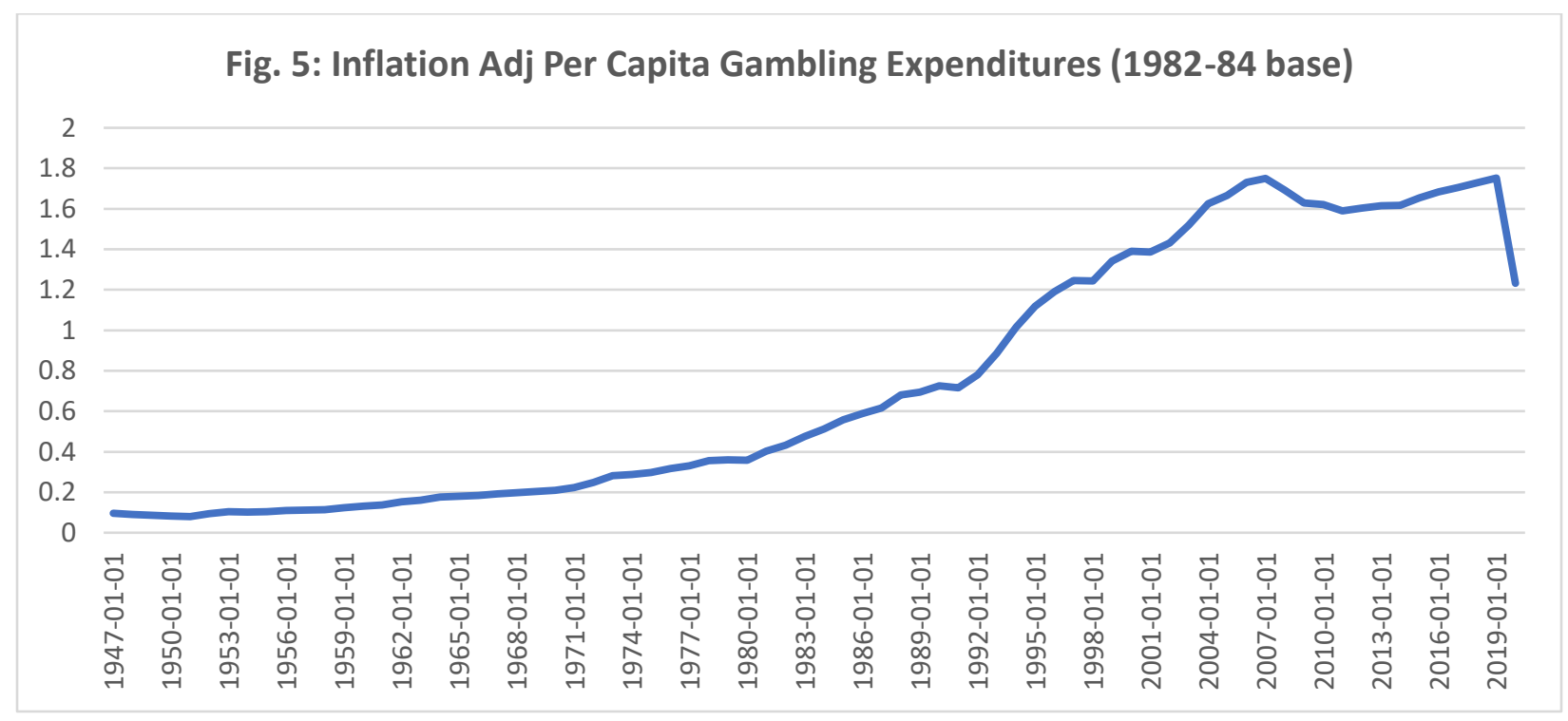

Source: U.S. Bureau of Economic Analysis, Personal consumption expenditures: Services: Gambling [DGAMRC1A027NBEA], retrieved from FRED, Federal Reserve Bank of St. Louis;

https://fred.stlouisfed.org/series/DGAMRC1A027NBEA, June 21, 2021; and US Census Bureau, Census of Housing and Population, 
Fig. 6: Gambling Exp as Pct Recreational Services

35

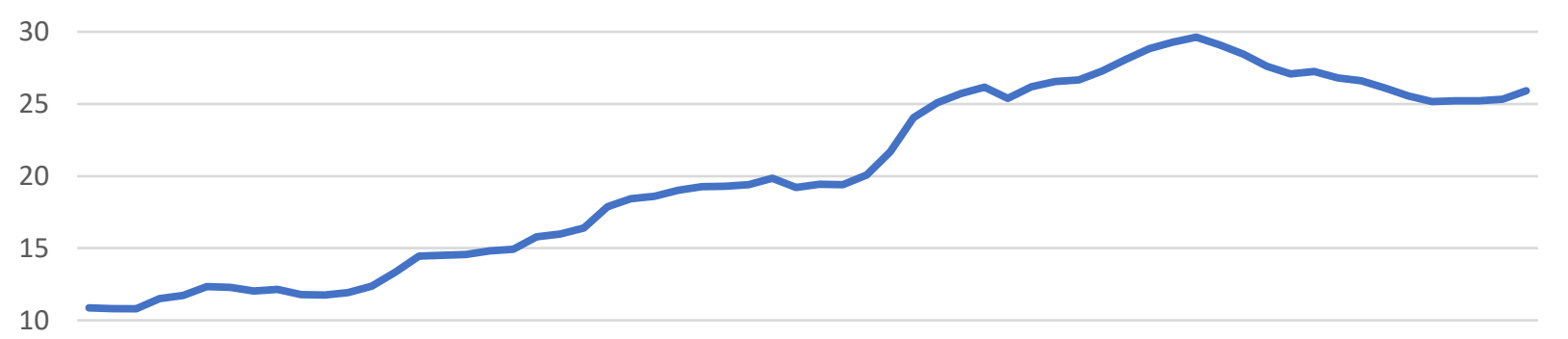

5

0

兽

Source: U.S. Bureau of Economic Analysis, Table 2.4.5U. National Income and Product Accounts, Personal Consumption Expenditures by Type of Product,

https://apps.bea.gov/iTable/iTable.cfm?reqid=19\&step=3\&isuri=1\&1921=underlying\&1903=2017\#reqid=19\&step=

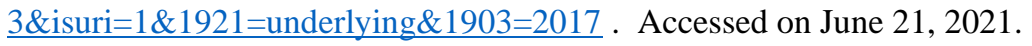

Fig. 7: Gambling as Pct of DPI

1.2

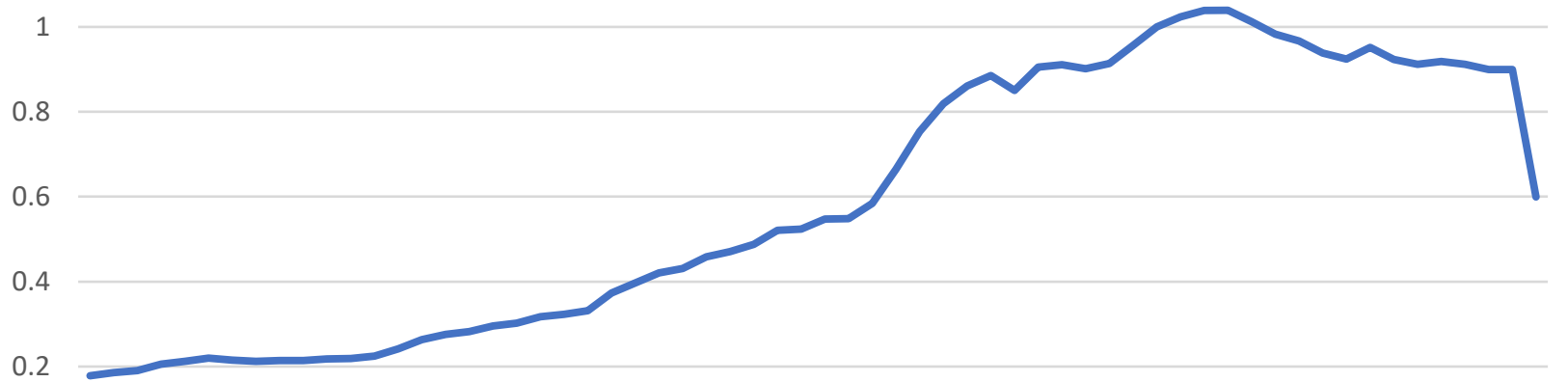

0

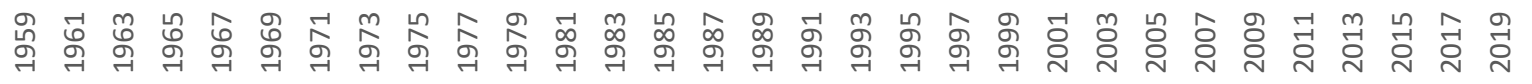

Source: U.S. Bureau of Economic Analysis, Table 2.1. Personal Income and Its Disposition, https://apps.bea.gov/iTable/iTable.cfm?reqid=19\&step=3\&isuri=1\&1921=survey\&1903=58\#reqid=19\&step=3\&isu

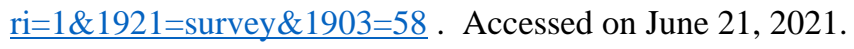


Fig. 8: Growth in Real DPI per Capita

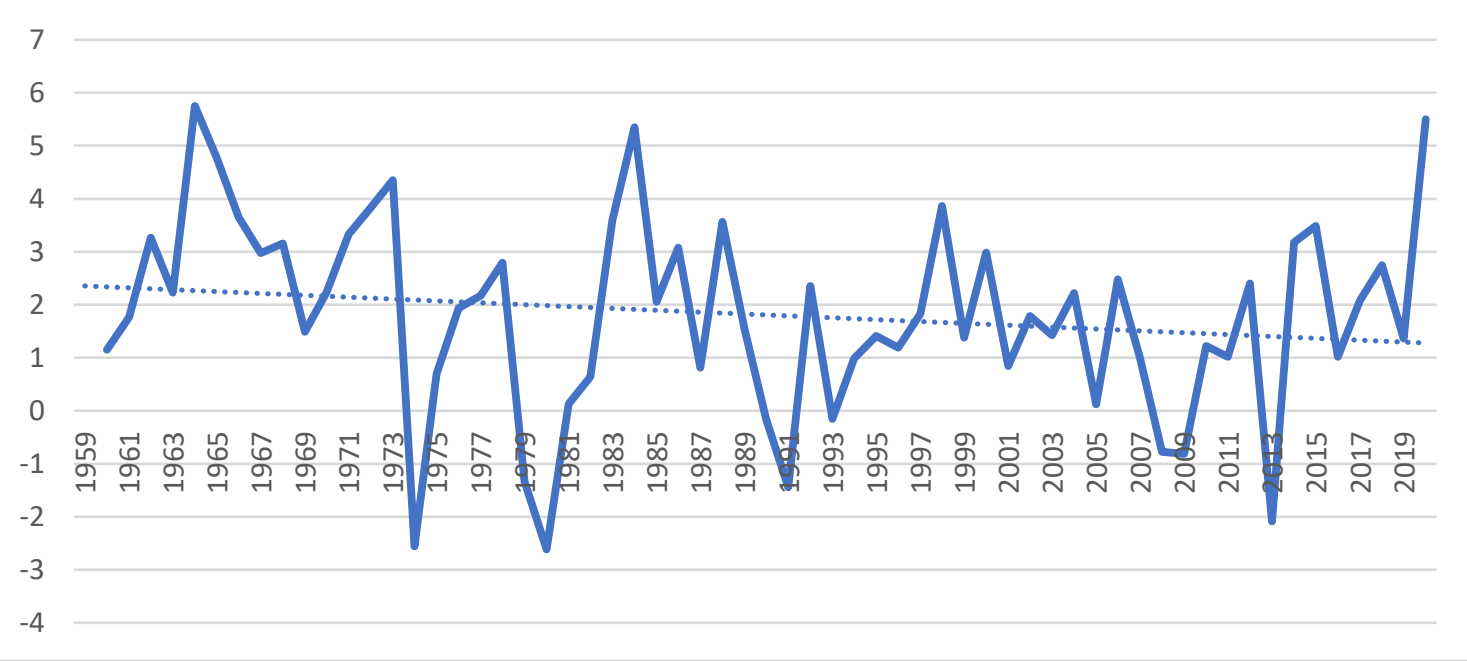

Source: U.S. Bureau of Economic Analysis, Table 2.1. Personal Income and Its Disposition, https://apps.bea.gov/iTable/iTable.cfm?reqid=19\&step=3\&isuri=1\&1921=survey\&1903=58\#reqid=19\&step=3\&isu $\underline{\text { ri }=1 \& 1921=\text { survey \& } 1903=58}$, Accessed on June 21, 2021.

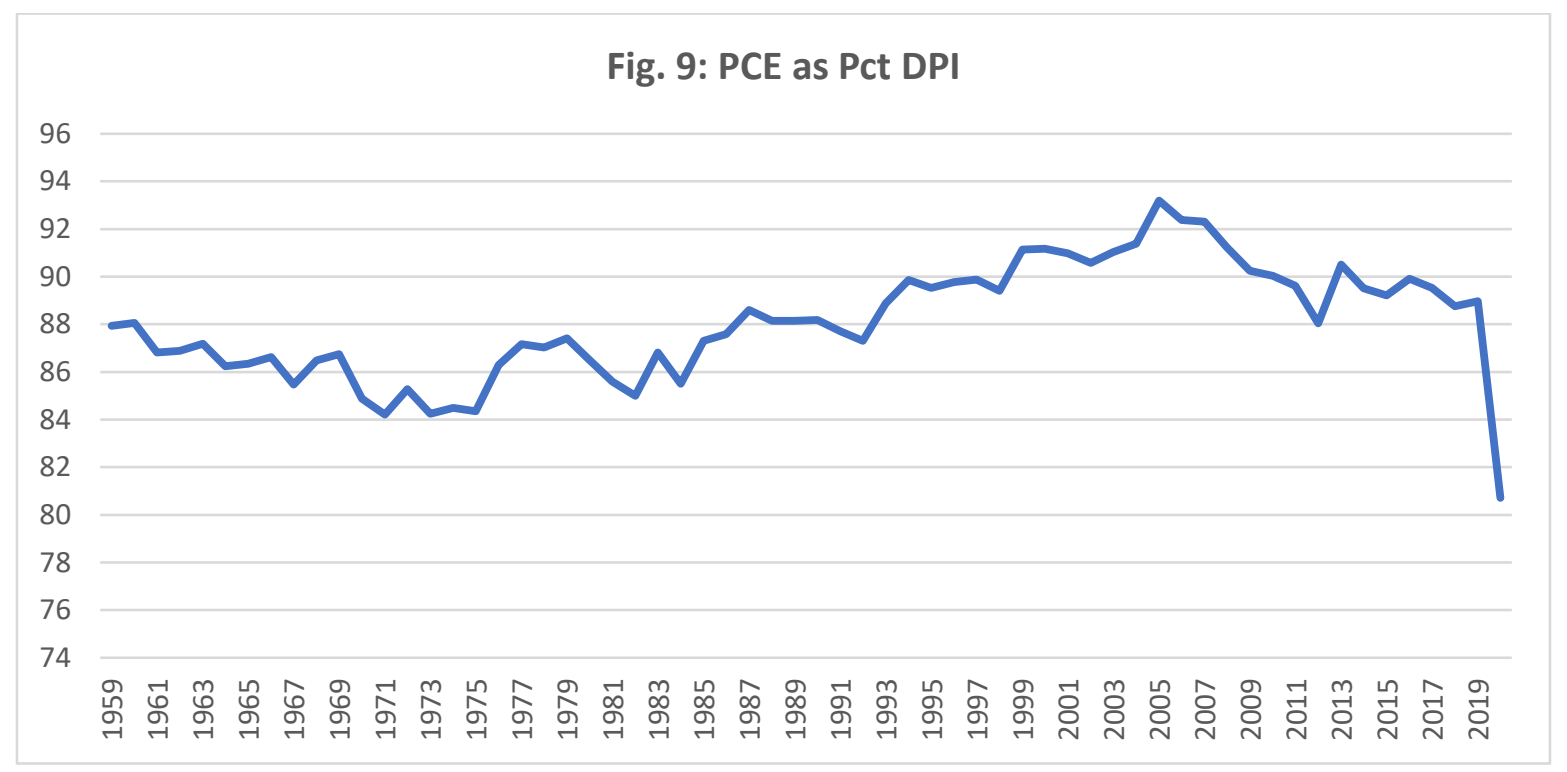

Source: U.S. Bureau of Economic Analysis, Table 2.1. Personal Income and Its Disposition, https://apps.bea.gov/iTable/iTable.cfm?reqid=19\&step=3\&isuri=1\&1921=survey\&1903=58\#reqid=19\&step=3\&isu $\underline{\mathrm{ri}=1 \& 1921=\text { survey } \& 1903=58}$. Accessed on June 21, 2021. 


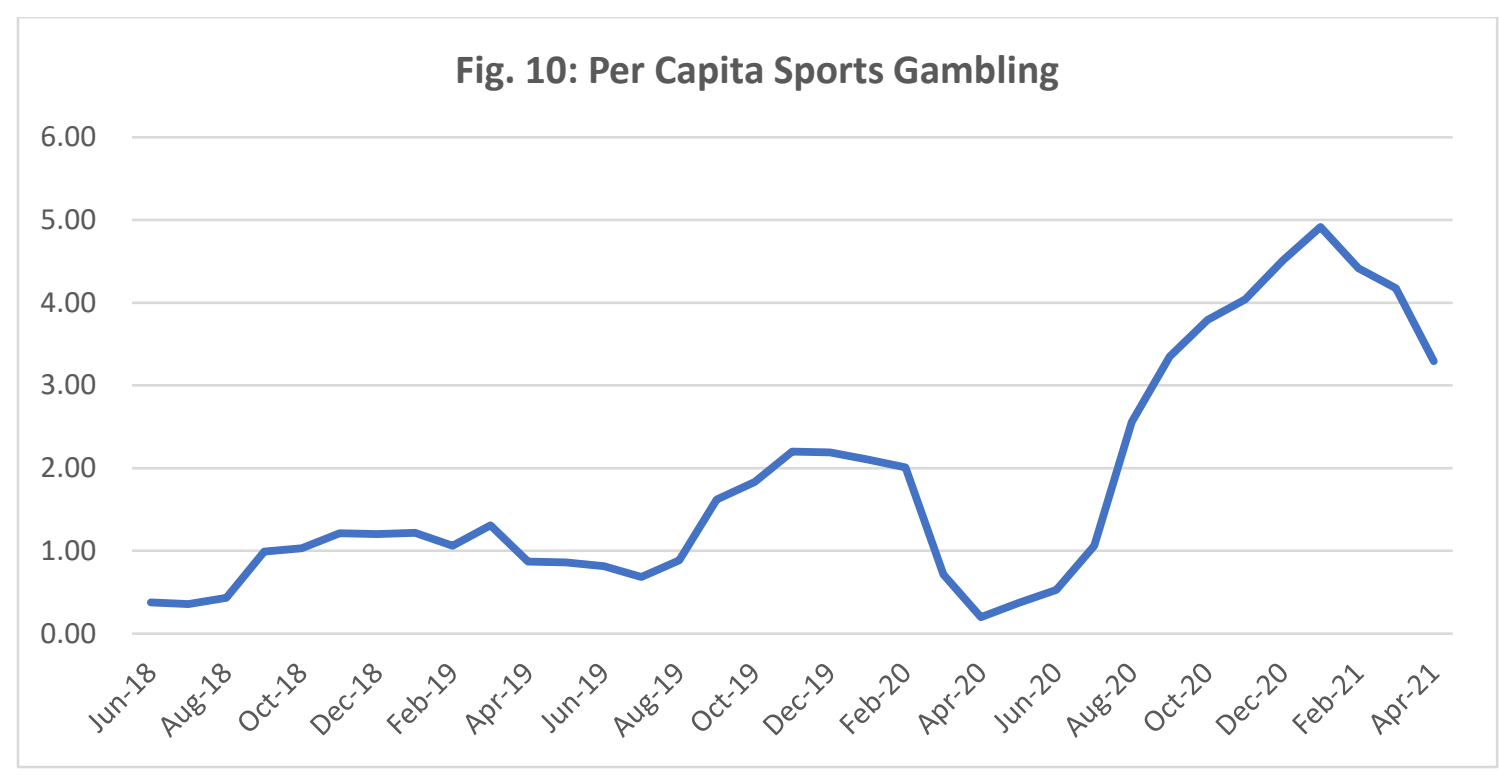

Source: Legal Sports Report. US Sports Betting Revenue and Handle. https://www.legalsportsreport.com/sportsbetting/revenue/ Accessed on June 2021.

Table 1-Regression Model

Dependent Variable: Natural log of inflation adjusted, per capita gambling expenditures Independent Variables:

$\mathrm{b}$

(Newey-West SE)

Intercept

$-10.45$

Ln Labor Force Participation Rate, Males, Age 16-24

0.488

(0.405)

Ln Inflation Adj. Real DPI

(0.127)

Adj. r-square: 0.943

$\mathrm{n}=62$

$p<0.05$ 


\section{Appendix}

PCE <PCE@bea.gov>

Thu 6/24/2021 6:14 PM

To:
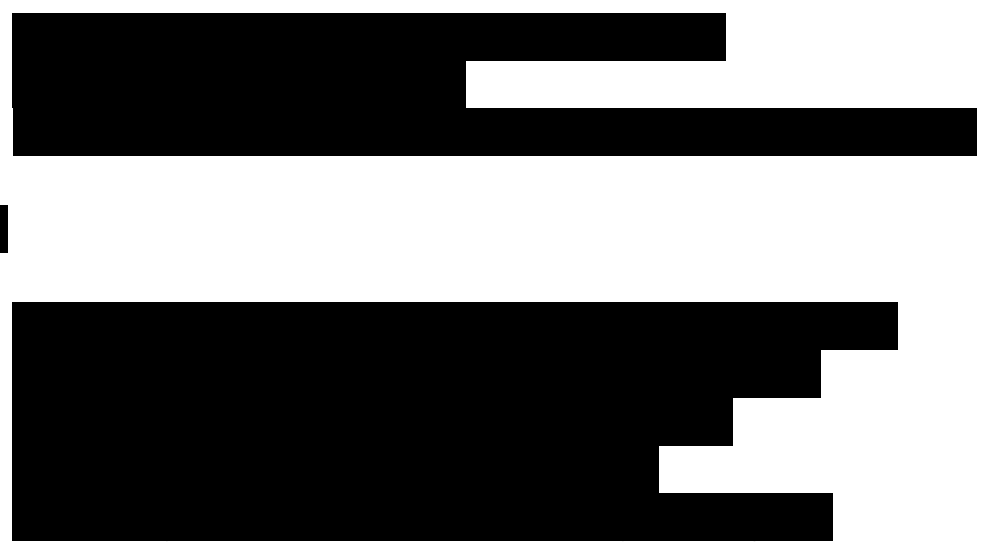

CAUTION: This email originated from outside of our organization. Do not click links, open attachments, or respond unless you recognize the sender's email address and know the contents are safe.

Thank you for your inquiry. Any gaming that does not fall under a pari-mutuel type betting system (e.g. horse races) or state and local or tribal lotteries will be under casino gambling, this includes Esports and online poker gambling. To be clear, the estimates only capture regulated gaming, any illegal gaming is not estimated and not included in the estimate.

The estimates for gaming are generally calculated using aggregated data. The BEA does not have estimates at a disaggregated level for Esports or online poker.

Please let us know if you have any further questions.

Section Chief, Business and Consumer Services Branch

Expenditure and Income Division

Bureau of Economic Analysis 
Dependent Variable: Natural log of inflation adjusted, per capita gambling expenditures Independent Variables:

b

(Newey-West SE)

Intercept

$-9.36$

Ln Labor Force Participation Rate, Males, Age 16-24

0.221

Ln Inflation Adj. Real DPI

$3.15^{*}$

(0.128)

Adj. r-square: 0.956

$\mathrm{n}=61$

$\mathrm{p}<0.05$ 